\title{
CONTENTS
}

Lonc E., Professor Zbigniew J. Jara—a Renaissance man of the third millennium.

- Frasca Jr. S., Kirsipuu V.L., Russell S., Bullard S.A., Benz G.W., Opercular lesion in wild black drum, Pogonias cromis (Linnaeus, 1766), associated with attachment of the sea louse Sciaenophilus tenuis (Copepoda: Siphonostomatoida: Caligidae)...................... 115

Hajek G.J., Kłyszejko B., The effects of Propiscin (etomidate) on the behaviour, heart rate, and ventilation of common carp, Cyprinus carpio $\mathrm{L}$

Hajek G.J., Kłyszejko B., Dziaman R., Paczkowska E., The effects of Propiscin on the cardiac rate of isolated heart of common carp, Cyprinus carpio L................................................ 145

Ghosh K., Sen S.K., Ray A.K., Growth and survival of rohu, Labeo rohita (Hamilton) spawn fed diets fermented with intestinal bacterium, Bacillus circulans.

Brucka-Jastrzębska E., Protasowicki M., Elimination dynamics of cadmium, administered by a single intraperitoneal injection, in common carp, Cyprinus carpio L.

Brucka-Jastrzębska E., Protasowicki M., Elimination dynamics of nickel, administered by a single intraperitoneal injection, in common carp, Cyprinus carpio L..

Winnicki A., Korzelecka-Orkisz A., Sobociński A., Tański A., Formicki K., Effects of the magnetic field on different forms of embryonic locomotor activity of northern pike, Esox lucius L.

Ramachandran S., Ray A.K., Inclusion of extruded grass pea, Lathyrus sativus seed meal in compound diets for rohu, Labeo rohita (Hamilton, 1822) fingerlings ........................... 205

Czerniejewski P., Filipiak J., Poleszczuk G., Wawrzyniak W., Selected biological characteristics of the catch-available part of population of vendace, Coregonus albula (L.) from Lake Miedwie, Poland

Pilecka-Rapacz M., Sobecka E., Parasites of young Baltic cod, Gadus morhua callarias L. in the Gulf of Puck, Poland

Witkowski A., Kaleta K., Kuryszko J., Kusznierz J., Histological structure of the skin of Arctic charr, Salvelinus alpinus (L.) from Spitsbergen.

Arockiaraj A.J., Haniffa M.A., Seetharaman S., Singh S., Cyclic changes in gonadal maturation and histological observations of threatened freshwater catfish "narikeliru" Mystus montanus (Jerdon, 1849)

an international journal for ichithyology and fisheries

\section{XXXXIIV (2)}

\section{4 \\ SZCZECIN POLAND}

ISSN 0137-1592 